The main guidelines are:

- Financing of Commissions shall have a high priority, and all Commissions shall have support for 'executive capacity and operating expenses'.

- The functions of regional desks of IUCN shall be to provide links with members in the regions (especially those in 'developing countries'), ensure that regional considerations are reflected in IUCN activities, and help catalyse the implementation of the World Conservation Strategy.

- Greater support should be given to conservation education, information, and public awareness.

-A priority shall be given to maintenance of the IUCN Red Data Book at the highest attainable level of reliability.

-IUCN should take whatever steps are necessary to examine, analyse, and if appropriate implement, a development programme to ensure that development activities take conservation into account.

\section{Conservation for Development}

With regard to this last point, the General Assembly welcomed a proposal by Maurice F. Strong, Chairman of the IUCN Bureau, for a 'Conservation for Development' programme. The programme is intended to enable IUCN to respond to requests from developing countries for assistance with conservation-related development activities. The programme would draw on the financial resources of development-assistance agencies.

The Conservation for Development programme, like the development theme of the World Conservation Strat egy, is a response to mounting concern by governments of developing countries that too much of the development which they are buying today is wrecking their chances of sustainable, reasonably self-sufficient development tomorrow.

\section{Charter of Nature}

IUCN's General Assembly in Zaire (1975), in response to a call by President Mobutu, had agreed that a Charter of Nature should be drawn up, the document to be signed by governments as signalling their intention to abide by broad conservation principles. In Ashkhabad the Charter was presented in draft form and its merits and demerits were hotly debated. The draft is to be rewritten and will be available for review by all IUCN members requesting a copy.

In a notable address to the General Assembly, H. E. Luis Echeverria Alvarez - former President of Mexico and now Mexican Ambassador to UNESCO - called for 'a new social and economic order, which will manage Nature's resources fairly and logically while aiming for a high and equitable quality of life'. This is the first time a major Third World figure has explicitly linked the New International Economic Order with conservation of Nature and natural resources.

Patrick Allen

IUCN Secretariat

1110 Morges

Switzerland.
UNDP/UNEP MEETING OF GOVERNMENT EXPERTS FOR DEVELOPING A COOPERATIVE PROGRAMME ON THE PRACTICAL APPLICATIONS OF RENEWABLE SOURCES OF ENERGY IN THE MEDITERRANEAN REGION, HELD IN MALTA, 9-13 OCTOBER 1978

Fifteen Mediterranean countries and the European Economic Community have agreed on a regional co- $x$ operative plan for the practical use of renewable sources of energy in the Mediterranean. This means that an effort will be made to harness the sun and the wind, and to use biomass consisting of plant and animal matter, on a larger and more efficient scale than hitherto.

The agreement was reached at a recent five-days' meeting, in Malta, of government experts from Cyprus, Egypt, France, Greece, Israel, Italy, Libya, Malta, Monaco, Morocco, Spain, Syria, Tunisia, Turkey, Yugoslavia, and representatives from the EEC. Two countries made specific proposals: Malta and Turkey offered to act as hosts of regional Mediterranean centres for renewable sources of energy. It was agreed at the meeting that the centre in Malta would deal with technical assistance and training and exchange of information in the region, while an existing national institution in Turkey would be designated as a regional centre for solar energy research and development. These recommendations must be approved, however, at a major intergovernmental conference of the Mediterranean coastal states.

The experts at the Malta meeting, which was cosponsored and co-chaired by the United Nations Development Programme and the United Nations Environment Programme, devoted most attention to the use of solar energy for such purposes as household water- and spaceheating, pumping and desalination of water for drinking and irrigation, drying and preserving of food, and greenhouse cultivation. Interest was also expressed in harnessing wind-power for generating electricity and pumping water, and in the production of biogas from organic wastes for cooking and localized electricity supplies.

Whereas large-scale substitution of conventional energy by renewable sources will be difficult, the experts felt that renewable energy technologies for reducing dependence on conventional energy and improving the quality of rural life are available now. Moreover, substantial work in this field is already being done in the Mediterranean region. 'While this is especially important for the developing countries in the Mediterranean', said Stig Andersen, UNDP Assistant Administrator, 'vigorous promotion of such use of renewable energy would clearly bring economic benefits to the more industrialized countries as well'. 'We now have a framework for exploiting the considerable expertise on renewable energy that exists on both sides of the Mediterranean,' declared Peter S. Thacher, UNEP's Deputy Executive Director.

The discussion highlighted the need for assisting developing countries to establish their energy balance-sheets and to integrate the use of renewable sources of energy in their energy development strategies. It was generally agreed that the potential uses of renewable sources of energy were intimately linked to the social and economic development of the Mediterranean developing countries, most of which are located in arid and semi-arid zones. Two such uses were stressed: water desalination and distillation, and water pumping.

Mr Andersen further expressed UNDP's willingness to supplement the financing of concrete projects that 
promote regional cooperation and attract financial support from Mediterranean governments. 'It is now up to the governments,' added Dr Stjepan Keckes, Director of UNEP's Regional Seas Programme, 'to move directly to the practical application of the agreements.'

Paul E. Ress

European Regional Information Officer

United Nations Environment Programme Avenue Jean-Tremblay 16

1200 Petit-Saconnex

Geneva, Switzerland.

\section{EIGHTH WORLD FORESTRY CONGRESS, HELD IN} JAKARTA, INDONESIA, 16-28 OCTOBER 1978

This Congress, organized by FAO, was attended by over 2,000 participants from some 90 countries. Of the participants, some 1,200 came from outside of Indonesia.

The theme of the Congress was 'Forests for People'. This marked a strong departure from previous meetings of this kind, which had tended to be along the lines of 'forests for foresters'. Discussions focused on the role of forests in rural development (how they support agriculture, by e.g. ensuring regular year-around supplies of water for irrigation, and by reducing soil erosion); on forests as potential sources of food (wild fruits and vegetables of hundreds of kinds, 'bush meat', and sundry sorts of new fodder); and forests for quality of life (as distinct from quantity of livelihood).

Thus the Congress dealt with the entire spectrum of products available through forestry. It looked not only at timber and fuelwood, but also at industrial materials such as oils and gums, drugs, and a host of organic chemicals, and also at genetic resources. It emphasized an expanded form of forestry - a multiple-sector activity that offers many things to many people.

From an environmental standpoint, the Congress was good news for conservationists. There was much talk of 'watershed services', stressing the critical role of forests. As delegate after delegate pointed out, forests affect the daily lives of people living many horizons away from actual forests - for example, city-dwellers who are dependent on adequate supplies of decent-quality water for their domestic household needs. Moreover, urban communities in many countries of the tropics suffer electricity shortages, public health problems, and other difficulties, related to far-off deforestation. In similar fashion, numerous dams and hydroelectric facilities have had their operational lives grossly shortened through deforestation-caused sedimentation, while irrigation systems, notably in Southeast Asia, are rapidly deteriorating through siltation from degraded watersheds. Above all, a number of forestry economists pointed out that watershed conservation, through reforestation and afforestation activities in addition to protection for existing forests, can be viewed as a 'paying proposition': conservation is not a luxury, since it can often be justified through its own cost-benefit arithmetic.

Surprisingly, the Congress did not deal with climatic repercussions of broad-scale deforestation in the tropics. Were tropical moist forests to disappear, as some observ. ers believe is not unlikely within the next three or four decades, there could be increased reflectivity of sunlight in the equatorial zone (the 'albedo effect'), plus a buildup of carbon dioxide in the Earth's atmosphere. Both these processes could upset global climatic patterns, and result in adverse weather trends in certain northern latitudes-including the U.S. grain-growing belt. The United States could then find itself with too little food, rather than too much, in what could be a far hungrier world.

All in all, the Congress highlighted the notion that modern forestry is a far cry from conventional forestry. In short, forests should be preserved as sources of many more goods and services than board feet of timber and supplies of paperpulp.

Norman Myers

P.O. Box 48197

Nairobi

Kenya.

FIFTH INTERNATIONAL SEMINAR ON NATURAL AREAS AND TOURISM, HELD IN THE PROVINCE OF CHUBUT, ARGENTINA, 21 OCTOBER-10 NOVEMBER, 1978

This enjoyable and encouraging event involved some aspects which seemed so admirable that they should surely be emulated elsewhere. In saying this we are not thinking so much of the haunting beauty of the semidesert 'pampas' through which we were driven in a comfortable bus for perhaps $3,000 \mathrm{~km}$ of our routing in the vast Province of Chubut, of the ever-generous fare with which we were regaled at every major stop and several minor ones, of the unique reserves for Sea-elephants (Mirounga leonina), Patagonian Sea-lions (Eumetopias jubata), Penguins (Spheniscus [Pinguinus] magellanicus), Humpback Whales (Megaptera sp.), and a 'petrified forest', or even of the grandeur of the snow-capped Andes in the superb Allerces National Park on the Chilean border, with its memorable walk among tall trees of Fitzroya cupressoides (in some cases exceeding 2,000 years in age), Nothofagus spp. (especially $N$. dombezi), and the subdominant bamboo Chusquea culeon; such conservationists' delights could scarcely be emulated anywhere else in the world in such variety and wealth. Rather we are thinking of how a handful of dedicated enthusiasts, with determined leadership, can relay to a far wider audience, their enthusiasm for Nature and natural areas and their conviction of what in the long run should be done to preserve them for the good of their country and ultimately of the world. In this case it was clear that their example is being paralleled in neighbouring provinces and countries, and that Latin America is joining rather widely in the Conservation Movement.* We also approved heartily of such touring seminars conducted in the field in various parts of a country of great potentialities environmentally, conservationally, and otherwise.

The much-needed conservation of natural areas and wildlife can evidently, and perhaps best or even only, be

*See, for example, the 'Manifesto of Curitiba: Declaration of Principles of the Environmental Movement', signed by the Presidents of four Brazilian conservation etc. organizations, of which we were given a copy during the Seminar; also the advent of the President of the Paraguayan Society for the Protection of Nature. 